\title{
ガラスと金属の接着機構 (II)*
}

\author{
池田豊** \\ Mechanisms on Glass to Metal Bonding (I) \\ by
}

Yutaka IKEDA

(New Nippon Electric Co., Ltd., Otsu)

\section{1 緒言}

金属とガラスを接着することは，いにし党より深い 関心がもたれ，その応用の面もきわめて広い。またそ のなじみの機構についても, 数多くの研究がなされ, 論文や総説もしばしば目に触れ, 留切な解説の掲載さ れている書籍も数多く刊行されている。

\section{$1 \cdot 1$ 金属とガラスの接着の歴史}

ガラスと金属の接着の起源は，エジプトで七宝類似 のものが作られた紀元前にさかの汸るといわれている。 11世紀になると，イタリアやフランスで七宝工芸が盛 えになり，金・銀・銅などを素地として，主として装 飾品が作られていたようである。廉価な鉄が活らろら に用いられるよらになったのは19世紀の初めといわれ る.

わが国で最初にほうろらが作られたのは，明治20年 といわれているが，23年には軍用の食器として初るて 使用された。矢の後, 主として台所用品圭中心に盛衰 を繰り返してきたが、プラスチック工業に押されるよ うになり, 最近では酒造タンク・化学用機器・冷蔵庫 ・電気洗濯機などにその持ら味を生かした独自の分野 が開けつつある。

また，数年前から話題になった電子発光板すなわり ELのらら、ほららら型と呼ばれる種類のものは, ほ らろらの技術がエレクトロニクスに応用されたものの 代表的な一例といってよからら。

ガラスと金属の気密封止の歴史は，ほうろらに比べ るとずっと新しく，気密性が実際に必要とされるむの に実用されたのは1879年のエジソンの白熱電球が最初 ではなかららか。これに次いで真空管・ブラウン管な ぞの電子管，けい光ランプなどの放電灯が発明され， これらの製品の死命を制するものとして, 気密封止の

* 原稿受理 昭和 43 年 3 月 11 日

*** 正会員 新日本電気(株) 大津市晴嵐2丁目
技術はきわめて重要視されるよらになった。

今日のエレクトロニクスの主役とも考劣られる半導 体素子や集積回路, 抵抗・コンデンサなどの回路素子, 水晶振動子・トランス・ろ波器, その他各種の電子工 業部品, もしくは冷㴡機コンプレッサなどの電気機器 部品なども気密封止:体 ( (19) 23) $^{2}$ ) るものが多くなってきた (図 1，2）。

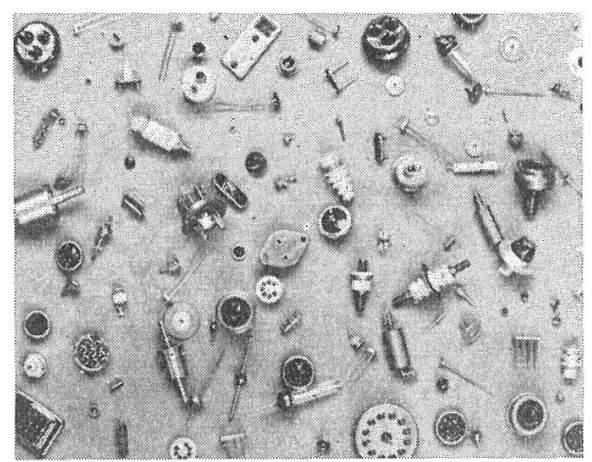

図 1 ハーメチックシール

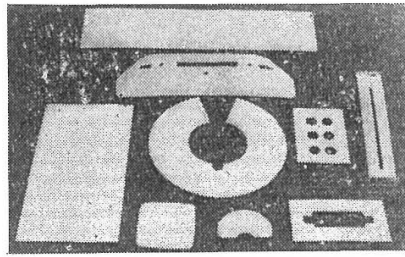

図2 ほうろう型 EL

\section{$1 \cdot 2$ 接着の技術}

ガラスと金属の接着の技術は工業的にみて大きく二 つの系列に分類することがでさる。一つはほらろらの 技術であり，他は気密封止の技術である。

金属とガラス状物質る融着させるという点において は両者はまったく同じであるが，製品に要求される機 能は大きく異なっている。すなわら, 前者では化学的 
に安定なガラス質が機戌的に強固に金属に接着するこ とが重要であり，後者では完全な気密の保持が要求さ れるとともに, 高度の電気的絶縁性が期待される場合 方多い。

ほらろらと気密封止とはいずれも強固な結合を得な ければならないが，それらに要求される特性・信頼性 扣よび経済性の点から，その材質はかなり異なってい る。前者に用いる金属はほとんど軟鋼であり，アルミ ニウムが一部特殊のものに適用される程度であるが， 後者は鉄・銅・アルミニウム・タングステン・モリブ デン・白金などの単体金属のほか，鉄・ニッケル・ク ロム・コバルトなどを含む数多くの合金が開発されて いる。

金属との接着用のガラスは，これらの金属との熱膨 張の相対関係が適切で，無理なひずみのかからないも のであることを基礎的条件とし，金属との濡れ・なじ 又が良好であることを考慮した材質のものが選択され る.

ガラスと金属の接着機構に関する報文は，古くから 行なわれているほうろうに関するものが圧倒的に多い が，近年にはむしち学問的に興味の深い気密封止の問 題が多くとり上げられているよらである。

本編に打いては去れらの両方の場合をとりまとめ， 使用される金属とガラスの材料の種別に従って，それ ぞれの場合についての接着の機構に関して, 主として 電子工業の立場を中心として総合的に解説する。

\section{2 鉄とガラス}

\section{$2 \cdot 1$ ほうろうの接着}

$2 \cdot 1 \cdot 1$ 鉄とガラスの結合 ほららうに稀ける鉄 とガラスの結合については，古くから種くの技法によ って接着機構の解明が試久られて和り, 多くの学説が 提唱されている。

（1）機戌的結合：金属とガラスとが相互に入り組ん だ界面によるかみ合いの結合である。あらい界面が生 成されている場合に接着強度が強いといら一般的傾向 から, 最も考完やすい機構である. 電気化学的侵食作 用，金属表面酸化の不均一，あるいはガラス中の金属 酸化物の還元による樹状晶 (Dendrite) の析出などが 機械的結合の原因としてとり上げられている。

電気化学系列の高い金属は, 飽和溶液中に和ける場 合と同様に，溶融ガラス中の低位の金属を置換すると 考觉ると，ガラスの下地ほらろら中の酸化ニッケルと 酸化コバルトが，鉄板の表面から溶解拡散した鉄と置 き換えられて鉄表面に析出し，これが接着の基礎とな るといらことが考えられる。図 3 は酸化コバルトを含 有する場合の電気化学的侵食の状況を示すもので, こ の場合の化学反応は

$$
\mathrm{Fe}+\mathrm{CoO} \longrightarrow \mathrm{Co}+\mathrm{FeO}
$$

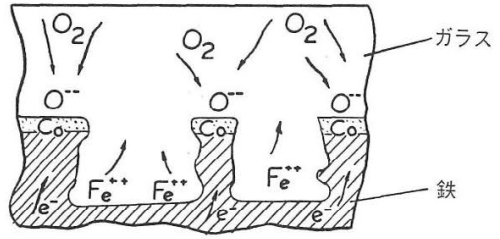

図 3 酸化コバルトを含有するほうろう フリットによる電気化学的侵食

と考光られる。

鉄板に汪うろらフリットを吹き付けて乾懆暁付けを 行なう場合，鉄の表面が酸化され，この酸化物はほう ろら中にいったん溶解した後, 分解して $\alpha$ 鉄を表面に

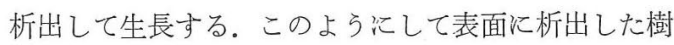
状晶が汇らろらに和ける鉄とガラスの固着に奇与して いるという解釈が提唱されている。

このように融着のプロセスで界面があらくなる場合 のほかに，鉄板を予備処埋として酸洗いすることによ って，接着が強化されることもよく知られていると沶 りである。

典型的な機椷的かみ合いの状態を模型的に示せば図 4のと和りである. King らによれば，充分アニール したガラス自体の抗張力は約 $5.6 \mathrm{~kg} / \mathrm{mm}^{2}$ であり, 図のよらなかみ合いから得られる最高の強度は約 3.5 $\mathrm{kg} / \mathrm{mm}^{2}$ である。実際には界面の接着強度はガラス自 体の強度より強い場合が多く，この現象を機戌的かみ 合いの効果だけから説明することはらょっともずかし いようである。

界面の機械的結合状態の顕微鏡写真を示した報文は 非常に多く King, Pask, Healey, Harrison などの報 告に見ることができる。図 5 は鉄とケイ酸りーダガラ スの接着界面における典型的なかみ合わせの状態を示

(a)

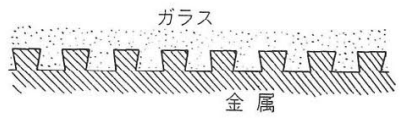

(b)

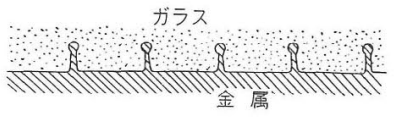

(a) 典型的鳩尾接合

(b) 現実の機械的かみ合いの状態

図 4 ガラスと金属の機械的結合模型

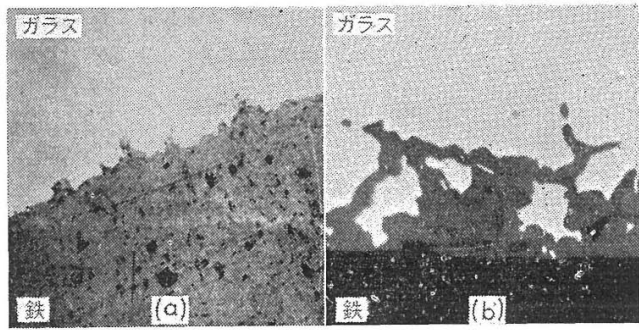

図 5 鉄とガラスの機械的結合の顕微鏡写真 


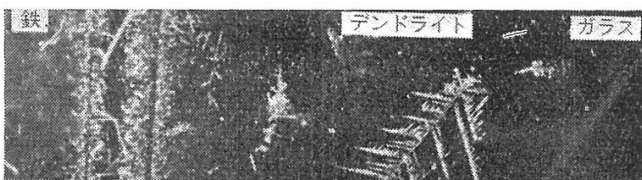

図 6 樹状晶（デンドライト）の顕䘗鏡写真

ず. この写真はガラス部分を薬品にて溶解した後, 断 面を研摩して撮影した影微鏡写真である。図6 は泳ら らうの接着界面に和ける拡散带に孤立したデンドライ トの結晶状態を示すものである。

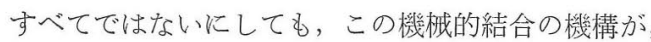
ほうろうの接着においてきわめて重要なるので每るこ とは疑問の余地はなからう。

（2）化学的結合：化学的結合之は, 界面に称いて相 接している金属とガラスの間の電子の共有が結合力と なっていることを意味する。 Pask らはこの状況をき わ市て明快に説明している。すなおち, 界面を横切っ て連続的電子構造ができることが必要条件であり,こ れは鉄板に接したがラス層が $\mathrm{FeO}$ 孛飽和していると きに満たされる。りまりこの状態で“Balance of bond energy”が達成される。

図 7 は酸化された鉄とガラスが接した瞬間 $t_{0}$ から,

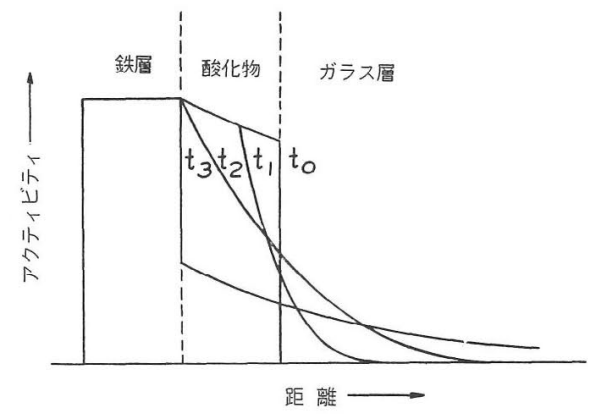

図 7 ガラス・鉄中間層に拈ける浸透距離 と鉄のアクティビティ

時間の経過とともに, 表面酸化物が溶出する状態に対 応する鉄のアクティビティを示している。 $t_{2}$ は最後の 酸化物の 1 分子層が溶出する瞬間に相当し，鉄とガラ スが接した界面の部分だけについて考光ると，この瞬 間は雨者は平衡状態にあるとい觉る。实際にはガラス 相中に飽和された $\mathrm{FeO}$ はガラスの内部に向かってど えどて拡散していくから，この平衡状態を長時間保持 することはできないが，実際の接着にはこの状態が要 求される。酸素の供給がなければ， $t_{3}$ で示されるよう にガラス相中の $\mathrm{FeO}$ は拡散してしまい，鉄板に接し た部分のガラス中の $\mathrm{FeO}$ の濃度は平衡濃度よりかな り低くなってしまう。

活らろら中に接着を促進するために添加される $\mathrm{CoO}$ の類,すなわち “Adherence oxide”が実際に有効で 劣る理由の一つは, 自身は還元されて鉄表面に析出し
て合金層を作り，放出した酸素は鉄と化合してガラス 中に溶出するために平衡学保持しガラス中の $\mathrm{FeO}$ が 相対的に不足側にずれるのを防ぐ働きを有するためで 西る。 $\mathrm{CoO}$ は $0.5 \%$ ぐらい添加されれば適当な熱処 理で界面に針状結晶を析出し, さららろ添加量が增加す るとデンドライトが析出する。こ杂らの析出物は六方 最密充てん型の金属コバルトである。そしてもら一つ の理由として，この析出したデンドライトが機械的結 合を強めることが加方っている.

このように化学結合の基本原理はきわめて簡単であ るが，実際の化学反応はかなり複雑なものである。

(3) 遫移層結合：鉄とガラスの相のほかに中間酸化 物（もしくは他の化合物）の相の三相から成る結合で, 遷移層 (Transition layer)による結合と呼ばれるもの で，化学的結合の一つである。

この種の結合には，(a)金属表面に生成された酸化物 の浴け残りの層を介して,ガラスと金属が間接的に結 合する場合，(b)ガラス中の酸素と反応して新たに金属 表面飞生成された酸化物層を介乙て同様洁合する場 合, (c)酸化物以外の化合物から成る中間層学介して結 合守万場合が势る。

潘らろらの接着には鉄の表面を酸化ざせるとが必 須の条件であることから，鉄・酸化物・ガラスと漸次 变化する遷移層に上り結合しているといら考光方は無 理のない上らに思われる。しかしながらこの考光方に は $\mathrm{FeO}$ と鉄板の結合力は強くないといら問題がある。 また，暁きが不足すれば接着は弱いが，これを強く焼 くと強くなるという現象を単に酸化物の厚さの变化だ けから説明するのはむずかしい。

Kautz らの 1 我 $10 \mu$ 程度の酸化物層が存在するとい ら主張は，田代の報告で否定されて战り，もし酸化物 が存在してもきわめて薄いもので㐫り，これはガラス と鉄板が接した後にガラス中の酸化物によって酸化さ れたものと考党るべきであるう。なぜならば酸化鉄の ガラス中への溶解は相当速く, このような薄い溶外残 りの層を残した状態で融着を止めることは，きわわて もずかしいと考光ざるをえないからである。

（4）ファンデアワールス結合：2 個以上の原子が, 化学結合の生じない程度に近づいた場合に生ずる結合 であるが，この結合力は化学結合の場合より䦽抒よそ 2 けた程度弱いとされているので, ガラスと金属の接 着機構としては，この考克方は㐫まり重要視する必要 はなからう。

$2 \cdot 1 \cdot 2$ 接着の機構 湾ら弓ら作業は空気中で行 なわ水る場命が多いから，鉄板は常にある程度酸化さ れ，この酸化物がガラスに溶け込んた鉄の表面はあら くなる。また，鉄板表面にニッケルフラッシュが施さ れた場合, 牤よびフリット中に $\mathrm{CoO}$ が添加された場 
合に心，界面に局部電池が形成さ礼，鉄板表面に凹凸

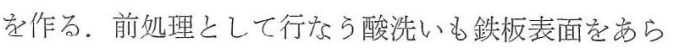
くする。これらが直接機械的か及合わせの原因となり， また, デンドライトの生成も機械的結合力を强めるも のと考光られる。

棌うらうのフリットには $\mathrm{CoO}$ が添加される場合が 多いが，この場合 $\mathrm{CoO}$ 自身が還元されて鉄板の表面 に析出すると同時に, 鉄板の表面索酸化させてガラス 相中の鉄イオンの濃度を高める。一方, 鉄板表面に析 出したコバルトは，表面に鉄ュバルト合金を作りこ のため表面の鉄の濃度を減少させ，ガラス相中の鉄の

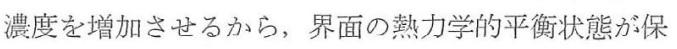
持されやすくなる。このように鉄化接するガラス相中 の $\mathrm{FeO}$ が平衡状態淿るとき, 強固な化学結合が生 げる。.

活うろうの接着機構は, いろいらの原因が重なり合 のた結果による機栈的結合と, 鉄とガラスの化学的結 合の総合によるものと考光るべきで㐫らう。

\section{$2 \cdot 2$ 気密封着}

$2 \cdot 2 \cdot 1$ 鉄とガラスの組合せ 鉄とガラスが気密 封止体と乙て使用可能であることは, かなり古く発表 されているが、実用的には第二次大戦中米国において, 特殊超短波用板極真空管に用いられた 戦後わが国にても開発されたが, 広く採用されるよう になったのは, トランジスタの発展に伴ってその容器 として使用されはじめてからである。

鉄の熱膨張係数は $135 \sim 140 \times 10^{-7} /{ }^{\circ} \mathrm{C}$ 程度で每り,

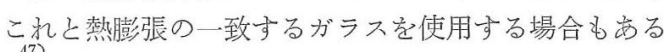
が, 一般飞熱膨張の大きいガラスは附薬品性・耐湿性 ・電気絶縁性が覀い。乙たがって，熱膨張が鉄より 30 〜 40\%小さいガラスを用い, 応力によるガラスの破壞 を防止するため, 封止体はコンプレッションシールと して設計されるのが普通である。

ガラスとしてはソーダライムシリカ系が多く用いら れる。管球用として広く用いられているいわ的鉛ガ

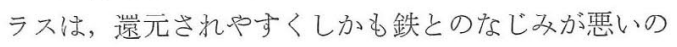
で、これを用いな礼ばならないと学は, 鉄沉銅・ク ロム・ニッケルなどを人ッキ寸る必要がある。

$2 \cdot 2 \cdot 2$ 鉄の酸化一般に金属とガラスの気密封 止漈しては, 金属を適度に酸化させ, この酸化物を 介して金属とガラスを融着させるのが普通であり，封
表 I 鉄の表面酸化物層の構成

\begin{tabular}{c|c|c}
\hline & $\begin{array}{c}\mathrm{FeO} \\
(\%)\end{array}$ & $\begin{array}{c}\mathrm{Fe}_{2} \mathrm{O}_{3} \\
(\%)\end{array}$ \\
\hline 表 面層 & 21.3 & 78.7 \\
中間 層 & 71.4 & 28.6 \\
内面 層 & 84.1 & 15.9 \\
\hline
\end{tabular}

化層は表Iの かにされている。年して金属之内側の低級酸化物, 外 側の高級酸化物之の間には, それぞれ連続した中間の 固溶体が存在しているもの之考觉られている。

$2 \cdot 2 \cdot 3$ 接着の機構 (1) 接着界面の中間層: 鉄 とガラスの封着界面の組織を観察した結果によると， 鉄の酸化物はガラスにきわぬて溶解しやすいため, 通 常の封止条件では，鉄之ガラスの間に未溶解の酸化物 は洼とえど残らない。したがって酸化物がぜい弱であ っても封止体の気密性には直接影響しない，鉄定酸化 させることが接着を強くする原因の一つとして考光ら れることは, 酸化物がガラス中に溶け去った後の表面 が学わてあらくなっていることである。图8 8 は鉄・ ガラス系の封着界面の電子顕微鏡写真であり, 同図(b) が上述の㐫らい界面を示す。

このか名合な状態と接着の強度はかなりよく対応 し, 酸化が足りない場合と饬まり進んだ場合は, 同図 (a)特よび(c)仙示す状態であり, その接着はいずれも弱 い。乙れら孝気密封止休の漏狆の発生状況に上って調 ベた結果の一例を表五に示す3。. 過酸化の場合に弱くな るのは, ぜい弱な未溶解の酸化物出るいは $\mathrm{FeSiO}_{4}$ な どの生成物が介在することによるるのと考兄られる.

（2）ガラス中に溶解した鉄の酸化物：鉄封止の場合 の酸化物の効果については, 界面に凹凸を作るという

表 II 鉄の酸化之接着の強度の関係

\begin{tabular}{|c|c|c|c|}
\hline \multirow{2}{*}{$\begin{array}{c}\text { 酸化温度 } \\
\text { (空気中10分間) } \\
\text { (C) }\end{array}$} & \multicolumn{3}{|c|}{$\begin{array}{c}\text { 熱衙撃試験に上る漏れ発生 } \\
\text { (漏れた試料/全試料) }\end{array}$} \\
\hline & $\begin{array}{c}\text { 室湿 } 330^{\circ} \mathrm{C} \\
2 \text { 回 }\end{array}$ & $\begin{array}{c}\text { 窒:湿〜 } 360 \mathrm{C} \\
5 \text { 回 }\end{array}$ & $\begin{array}{c}\text { 室温 } 400^{\circ} \mathrm{C} \\
5 \text { 回 }\end{array}$ \\
\hline 酸化なし & $0 / 10$ & $0 / 10$ & $4 / 10$ \\
\hline 400 & $0 / 10$ & $0 / 10$ & $2 / 10$ \\
\hline 600 & $0 / 10$ & $0 / 10$ & $0 / 10$ \\
\hline 800 & $0 / 10$ & $0 / 10$ & $0 / 10$ \\
\hline 1000 & $0 / 10$ & $0 / 10$ & $2 / 10$ \\
\hline
\end{tabular}

止の技術は酸化の技術で峁るともい方 れている。

鉄の表面を酸化させた場合，その酸 化被膜は均一な組成ではなく，その表 層と金属に接している部分とでは先の 組成を異にしている.鉄は750 $1050^{\circ} \mathrm{C}$ で強く酸化された場合, その表面の酸

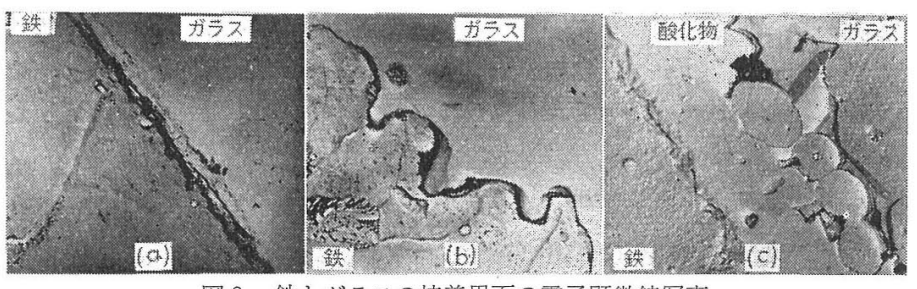

図 8 鉄とガラスの接着界面の電子顕微鏡写真 
こと以外にガラスのネットワークと鉄との化学結合を 促進するといらことも考光られる。鉄とガラスのネッ トワークは，鉄に接したガラス中に $\mathrm{FeO}$ が飽和され ているとき最も結合しやすい。また別の解釈をすれば， ガラス中に酸化鉄が溶け込むと，その部分のネットワ ークは，元れを構成すべき結合手の一部学解放して， これが基板表面の鉄之結合する之解釈される。

鉄の酸化物を㐫らかじ奶ガラス中に溶解させたもの をガラスと封着した後，ガラスをはがして鉄の表面を 顕微鏡で観察すると, 酸化物を添加しないガラス之封 着した場合に比べて，金属の侵食が促進されることが 図9によって明らかである。

封着の過程に扔いて鉄の酸化物がガラス中に溶け込 む前段階として浮遊している状態を, 四10の電子顕微

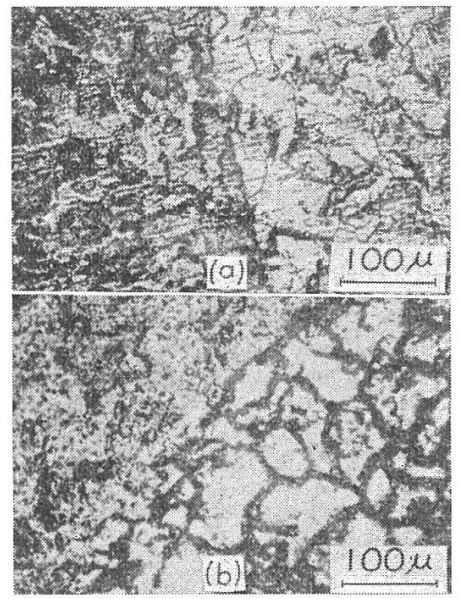

(a) $\mathrm{Te}_{2} \mathrm{O}_{3}$ を添加しないがラスの場合 (b) $\mathrm{Fe}_{2} \mathrm{O}_{3}$ を20\%添加したガラスの場合

図 $9 \mathrm{Fe}_{2} \mathrm{O}_{3}$ を添加したソーダライムガラスと鉄の 封着体よりガラスをはがした場合の鉄の表面

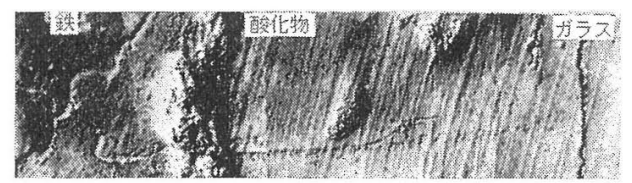

図10 ガラス層中に浮遊する鉄の睃化物
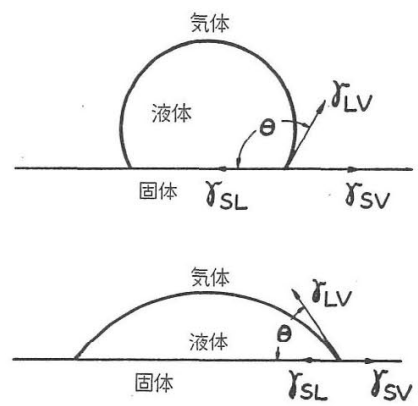

図11 固体表面に拈ける液体滴の濡れの平衡
鏡写真に見ることができる。

（3）ガラスと鉄の接触角：溶融ガラスと金属のなじ みの程度を表わす一つの因子として接触角がとり上げ られる。接触角之は図11のように定義され, 界面工ネ ルギの関数であって，Young の公式によって示され 28)54)

当、寺なわち

$\cos \theta=\frac{\gamma_{S V}-\gamma_{S L}}{\gamma_{L V}}$

$\theta$ : 接解角

$\gamma_{S V}:$ 固相一気相界面エネルギ

$\gamma_{S L}:$ 固相一液相界面エネルギ

$\gamma_{L V}:$ 液相一氛相界面エネルギ

つまり接触角が小さく、したがって需孔がよいために は，溶融ガラスの表面張力と金属とガラスの界面エネ ルギが低い洼らがよい。

接触角と封着のらえ囲気の関係についてはいくつか の報告があるが，その年の例を紹介すると次のと数りで 㐫る。可京我台，酸化されていない鉄の表面飞 $\mathrm{NaO}$. $2 \mathrm{SiO}_{2}$ ガラスを滴下すると, $900 \sim 1000^{\circ} \mathrm{C}$ の真空中で は $55^{\circ}$ の接触角を示す。滴下した初期にこ剠より小さ い場合は，鉄表面にガスが吸着されている場合で亦 る。かるく子備酸化した鉄を使用した場合には, 滴下 の初期以は約 $24^{\circ}$ の接触角を示すが，接触部の酸化鉄 がガラス中に溶解すると接触角は $55^{\circ}$ に增加乙，これ は鉄が酸化されていない場合と同じである。真空度を 下げると，接触角は鉄が酸化される速度と酸化され た鉄がガラスに溶解される速度の割合に從って変化す ร.

(4) 接着の理論：ガラス快气の主成分で岗る $\mathrm{SiO}_{2}$ が，酸素を頂点として中心傃原子が位置してい るいわゆるシリカ四面体を作りここ礼らの四面体は空 間的に積み重なり，互いに頂点の酸素を共有すること によって結合し，ネットワークを構成している。

ケイ素原子の回りの酸素のらち, 他の四面体之共有 されている架橋酸素の数学 $Y$ 個, 四面体間の結合に寄 与しない非架橋酸素の数を $X$ 個とし, ガラス中の酸素 とケイ素の比を $R$ と, ケイ素の回りの酸素の配位数 をZとすれば

$$
X+Y=Z, X+Y / 2=R
$$

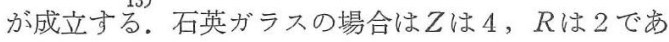
るから $X=0, Y=4$ ということになる。

ここでネットロークを構成しない修飾酸化物が導入 されると， O/Si 比すなわちRが大きくなるが，ネッ トワークを構成しているケイ素の回りの酸素の配位数 $Z$ は 4 以外の值取り光ないから，必然的に非架橋酸 素Xの数が増加し，元の分だけ架橋酸素 $Y$ の数が減少 する。これはネットワークの結合力，すなわちガラス の内部エネルギが減少し，またガラス中の酸素のフリ 
ーボンドが増加することを意味している。このフリー ボンドは最初は導入酸化物と結合してガラス中に溶解 されるものであるが，接着部にこのような内部エネル ギの低い層ができて，これが溶融状態で金属と接すれ ば，このボンドは容易に金属表面と結合すると考觉ら れる．封止に際して金属表面を耐化させれば，内部工 ネルギの低い層が界面に生成し，ネットワークの構成 にあずかっている酸素のボンドを切断し，金属側に向 ける㗢きが生ずる。

ガラスが酸化鉄を溶解すると，その熱膨張率はいく ぶん上昇し，屈伏点はわずかに低下することから，次 のような封着機構が考学られる。がラス中に溶解され た酸化鉄は，ネットワーク形成酸化物とネットワーク 修飾酸化物の二つの状態で平衡を保っているとすれば, 後者がシリカ四面体から成るネットワークの酸素架橋 を切断すると，ネットワークの結合力は減少し，その 結果熱膨張率は増加し, 屈伏点は低下すると考えられ る。また，切断された接合手が基板と結合すると考光 ると，ガラスに酸化鉄を溶解させることにより，鉄基 板に対する接触角が小さくなるといら図12に示すよう な現象も説明できる.

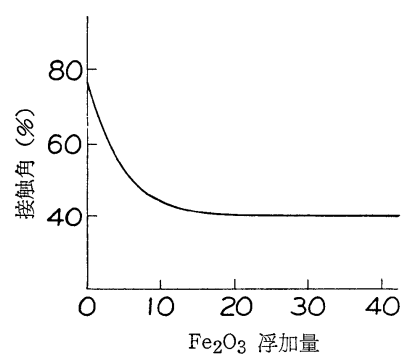

図12 酸化物を添加したソーダライム ガラスの鉄基板上における接触角

(a)<smiles>CO[Si]1(OC)CC([Si](C)(OC)OC)O1</smiles>

(b)<smiles>COC(C)(OC)[Si](C)(C)OC</smiles>

(c)<smiles>CO[Si](C)(C)O[Si](C)(C)OC</smiles>

(Fe) (Fe) $(F e$ Fe (Fe) $(\mathrm{Fe})$ (Fe) $(\mathrm{Fe}$

(a) ガラス状態

(b) 酸化物溶解による網目構造の搏緩

(c) ボンディングの完結

図13 鉄とガラスのボンディングの機構
以上のことから考えられる一つの機構を模型的に図 示すれば図13のと叔りである。

$$
3 \text { コバールとガラス }
$$

\section{$3 \cdot 1$ コバールとガラスの組合せ}

ガラスと金属の気密封止に理想的なものとして開発 されたこの合金は、コバールまたはフェルニコと呼ば れ，鉄54\%ニッケル29\%コバルト17\%程度を標準とし， 熱膨張曲線に屈曲点があって, ホウケイ酸ガラスたと えば Corning $\$ 7052$ ときわめてよく近似しており， 封着体は常温からカララが軟化を始める温度まで昇降 しても，ほとんど無ひずみの状態が維持される.

\section{$3 \cdot 2$ コバールの酸化}

この合金の酸化についてはかなり多くの研究がなさ れている.

$3 \cdot 2 \cdot 1$ 酸化速度図 14 (4) 件の範囲を示すもので，よい接着を得ることのでさる 酸化膜の厚さには図の (a)(b)に示す上下限があり，この 限度内に和さめるように温度と時間を制御しなければ ならない。また，V字型の点線で囲まれた範囲は酸化 膜がはく脱する条件とされている.

なお，同じ条件で酸化させても，酸化の前の水素ふん 囲気中における熱処理条件によって, 酸化速度は影響 を受ける。すなわち図15，16に示すように、コバール

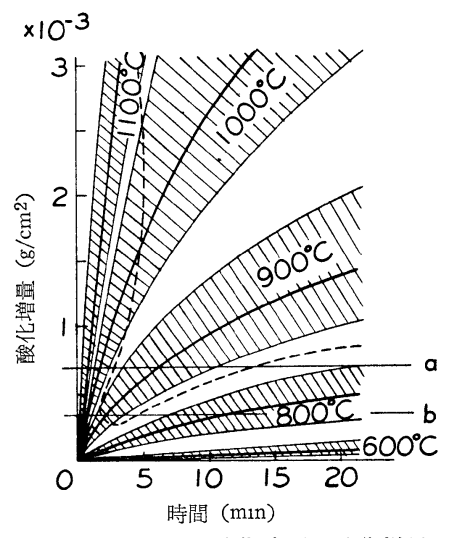

図14 コバールの酸化時間と酸化増量

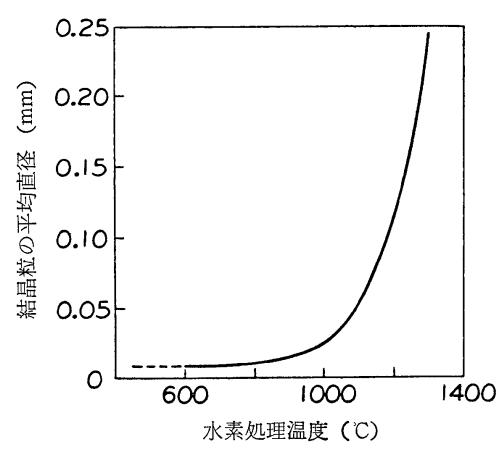

図15 コバールの水素処理温度と結晶粒度 


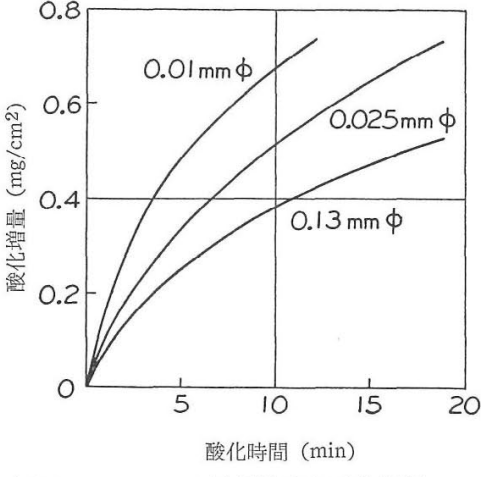

図16 コバールの結晶粒度と酸化增量

の水素処理温度が処理後の結晶粒径支配し，その結 晶粒度が酸化の速度に影響する。

$3 \cdot 2 \cdot 2$ 酸化生成物 コバーールの酸化は放物線則 に従うが， $700^{\circ} \mathrm{C}$ から $800^{\circ} \mathrm{C}$ の間の活性化エネルギは

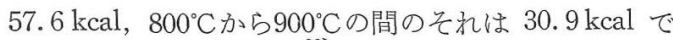
あることが知られており， $800^{\circ} \mathrm{C}$ 付近を境として酸化 の機構が変化すると考えられる。

コバールの酸化は結晶の粒界から起こる。図17は酸 化温度を変えた場合の酸化進行の状況を示し，それら の粒界酸化物に, マイクロビーム X線を照射して㵊影 した回折写真を同図下段に示す。表面酸化物は高温に なるほどスピネル型の $\mathrm{Fe}_{3} \mathrm{O}_{4}$ が多く，低温ではへマ
タイト型の $\mathrm{Fe}_{2} \mathrm{O}_{3}$ の混入量が増加し，また ま $800^{\circ} \mathrm{C}$ 以上 では岩塩型の $\mathrm{FeO}$ る生成される。

$\mathrm{X}$ 線回折では $\mathrm{Fe}_{3} \mathrm{O}_{4}, \mathrm{CoFe}_{2} \mathrm{O}_{4}$ 施よび $\mathrm{NiFe}_{2} \mathrm{O}_{4}$ は よく似て怙り判別はもずかしいが，元素分析の結果で はこの合金の表面酸化物は鉄の酸化物である。袁亚は 酸化温度と表面酸化物の組成の関係を示すものであ る。蹎微鏡的に酸化物の種類を判別することはむずか しく,さきに述べた $800^{\circ} \mathrm{C}$ 付近での酸化機構の変化に 対応する差は見いだせないが，酸化温度のだいたいの 推定は可能である.

$3 \cdot 2 \cdot 3$ 酸化物の表面状態 図18は, ユバールの 酸化温度と表面状態の関係を示するのである。この合 金の酸化で興味のある点は，高温では $\mathrm{Fe}_{3} \mathrm{O}_{4}$ には方 向性がないが，低温になるに従って（110）面が試料表 面に平行な選択方位を持っていることであって，この 変化は連続的であり, $800^{\circ} \mathrm{C}$ に和ける酸化機構の変化 を説明することはできない。結局, $800^{\circ} \mathrm{C}$ 以下の酸化

表吕 コバールの酸化温度と表面酸化物の組成

\begin{tabular}{c|c|c|c}
\hline \multirow{2}{*}{$\begin{array}{c}\text { 酸化温度 } \\
\left({ }^{\circ} \mathrm{C}\right)\end{array}$} & \multicolumn{3}{|c}{ 酸化物組成 (\%) } \\
\cline { 2 - 4 } & $\mathrm{Ni}$ & $\mathrm{Co}$ & $\mathrm{Fe}$ \\
\hline 750 & 2.1 & 4.0 & 93.9 \\
850 & 3.8 & 4.8 & 91.4 \\
900 & 5.9 & 5.8 & 88.4 \\
\hline
\end{tabular}

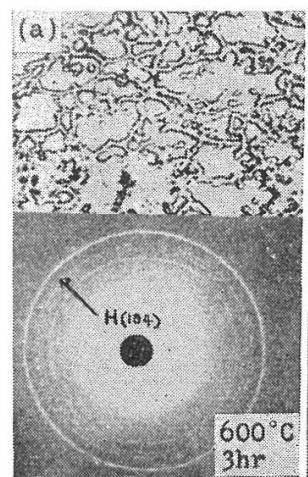

図17 コバール結晶粒界に生成した酸化物
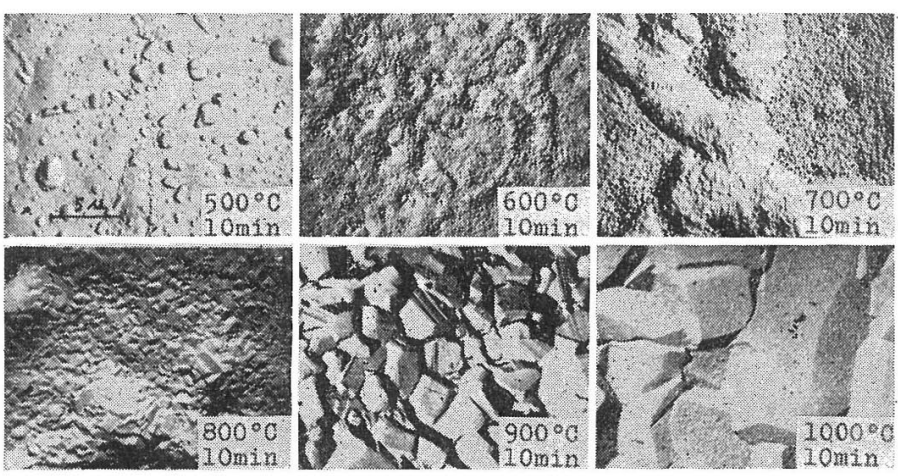

図18 コバールの酸化温度と表面状態

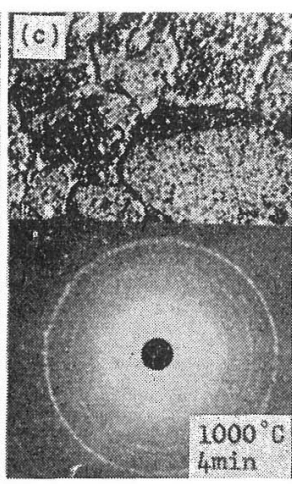

$1000^{\circ} \mathrm{C}$

\section{mitar}




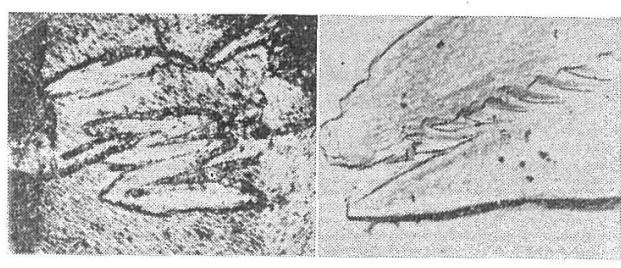

図19ａ変態を生じたコバール酸化表面

成させて封着した実験結果の一例を表IVに示す。

$3 \cdot 3 \cdot 2$ 封着体の色調 封着の時間は温度の関数 であり，高ければ短く低ければ長くすればよい。これ らの条件の適否は封止体の色調で管理することができ る。一般には“深又があってやわらか心感じ学与觉る 明るい㸚ずみ色”であって明度 (Value) 4 〜，彩

表IV コバールの酸化物とその接着性

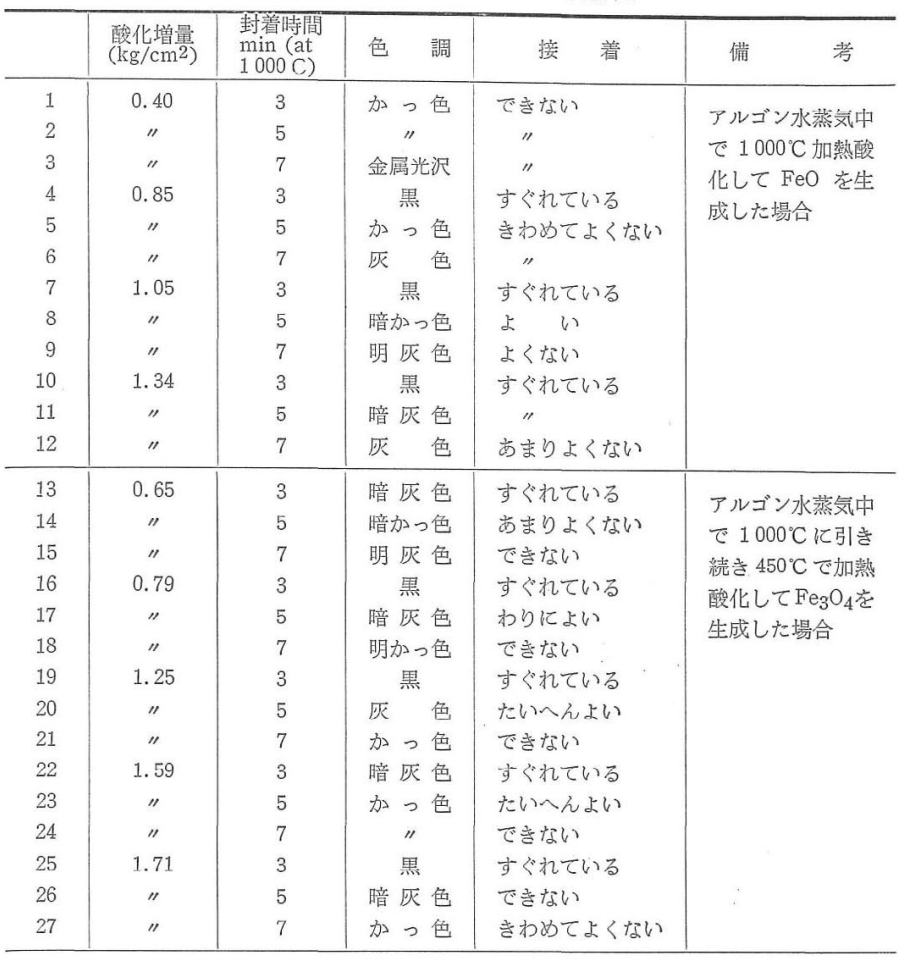

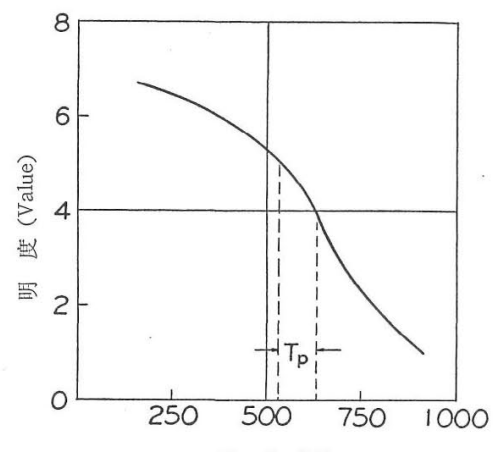

温 度 $\left({ }^{\circ} \mathrm{C}\right)$

図20 予供酸化温度と明度との関係
度 (Chroma) 0 0.1 がよいとさ䃿ている。明度は子 備酸化の温度のみに多く支配され, 彩度は封着加熱時 間に活とえど依存する。図20，21はとれらの関係を示 す。図中の $\mathrm{Tp}$ ， Rd はそ礼辇狆適切な明度・彩度を 得る条件である。

\section{$3 \cdot 4$ 接着の機構}

$3 \cdot 4 \cdot 1$ 接着界面の中間層 ユバールとホウケイ 酸ガラスの接着性はきわ女て良好であるが，酸化物の コントロールが接着の機構に重要な働きを持っている。 図22は酸化の程度を変えた場合の接着部の組織の一例 である。図(a)は，予備酸化被膜の厚さ $\mathrm{cm}^{2}$ あたり 0.13 $\mathrm{mg}$ のコバールを封着したもので，膜厚が薄すぎて気 密性が悪い場合，(b)は $0.215 \mathrm{mg}$ のもので適正な封着 体，(c)は0.70 mg のもので膜厚が厚す ぎて気密珄の悪い例である。これによ って明らかなように，合金に接するガ ラス部分には，酸化物を相当量溶解し た中間ガラス相が生成されて欮り，こ れの厚さないしは濃度が最適の場合に すぐれた接着が得られる。

コバールの予備酸化が過度気味で㐫 って封着時間が長い場合には，乙ばし ば接着界面にガラスの失透現象が起こ る。図23(a)は界面の失透結晶の生成状 況，(b)は結晶の拡大写真である。

\section{$3 \cdot 4 \cdot 2$ 接着界面における拡散} 適正な条件でなされた場合の、コバー ル・ガラス封着体の接着界面近傍の化 学組成の微視的変移の状態を, X線マ イクロアナライザにて解析した結果を 図24k示守. 界面近傍に Ni 㸱よび Co の濃度の高い部分が見られるのは，Fe のガラス中への拡散速度が大きいこと を意味している。

$3 \cdot 4 \cdot 3$ ガラス中に溶解 したコバ 一ルの酸化物 また，一方コバールを

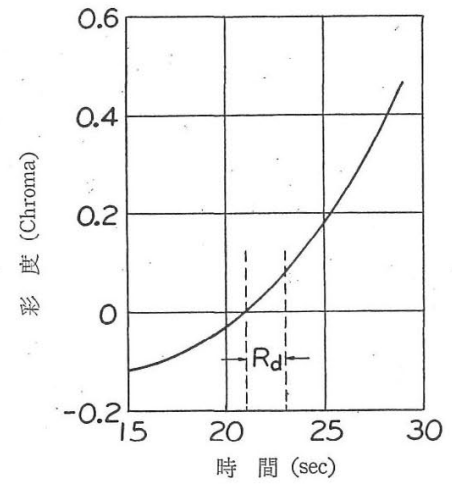

図21 封入加熱時間と彩度との関係 


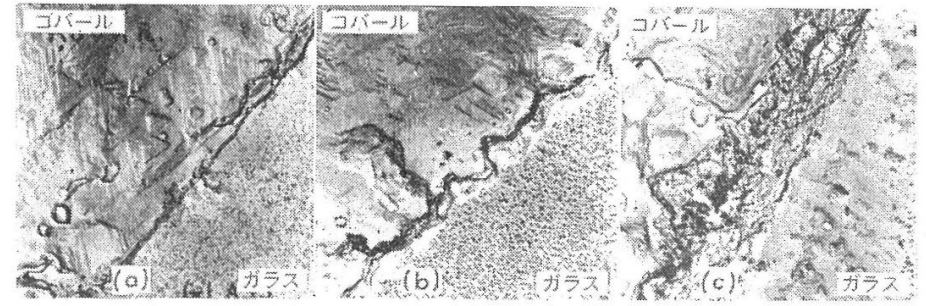

図22 コバールとガラスの接着界面の電了顕微鏡写真

粒界部分でくさび状にコバール内部に 食い込九だような形で生成されている2) ことから，酸化物を溶解したガラスと コバールの直接的な結合と, 粒界部分 に拈ける未溶解酸化物を介した結合 と, 二つの機構で共存していると解釈 一れば，矛盾はなく説明できる。顕微 鏡的な観察結果では，この場合には機

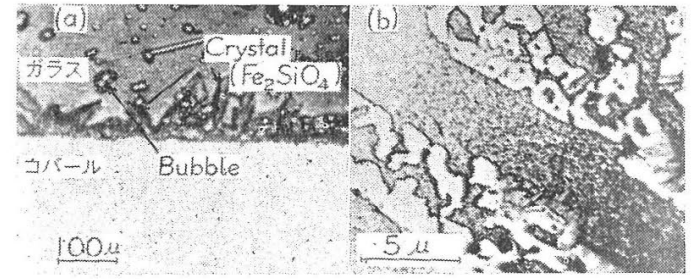

図23コバールとガラスの接着界面に生成した失透結晶

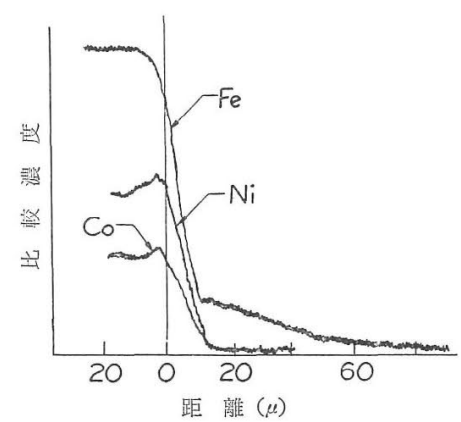

図24コバールとガラスの接着界面に扔ける 各元素の拡散状態

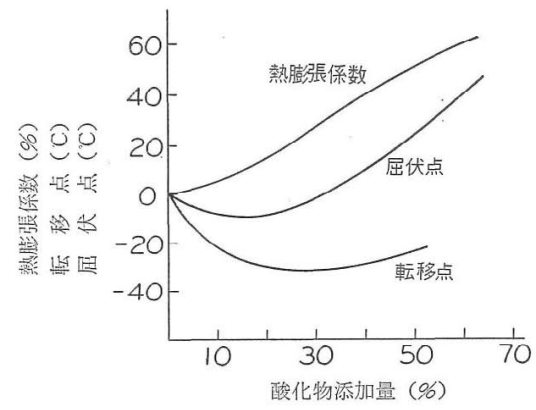

図25 ホウケイ酸ガラスにコバールの酸化物を 添加した場合のガラスの熱膨張特性の変化

酸化させる代わりに，コバールの表面酸化物をあらか じめガラス中に添加しておくことによって，すぐれた 接着が得られることが知られている。これらの現象か ら考觉ると, 未溶解酸化物が界面に介在して接着に寄 与していると考光た區うがよいように思わ机る。

しかしながら、コバールと午の表面酸化物の密着性 の覀いものは, でき上がった封着体のガラスと金属の 接着もよくないといら事実は, このような解釈では説 明はもずかしい。この点は, 表面酸化物がコバールの
械的か久合いに上る效果はあまり大きくなさそらであ る.

ホウケイ酸ガラスに方る程度コバールの酸化物が溶 け込学之，図25のようにガラスの熱膨張は大きくなり 転移点と屈伏点は低下する。 また, コバール基板に対 するホウケイ酸ガラスの接触角は, 酸化物の溶解量が ある程度に達すると最小になる。

$3 \cdot 4 \cdot 4$ 接着の理論 以上のことは, ガラスの中 に酸化物が溶け达さことによってネットワークの結合 力が低下乙て和り，只のため熱膨張率が增加し屈伏点 が低下していることを意味している。屯た，ホウケイ 酸ガラスは一般に分相しやすい傾向を有して和り, 分 相したガラスは異常膨舞の温度域が広いことが特長で あるが，酸化物添加の效果が屈伏点の低下ょり転移点 の低下の活うが大きいことは, 異常膨張の温度域が広 がっていること示している。

これらのことから予備酸化されたコバールの表面酸 化物がガラス中に溶け込及，ネットワークの結合力を 弱め,ネットワークの結合手が切れて, 合金表面と結 合しやすくなるものと解することができる。去してこ の接着は鉄とソーダライムガラスの場合と同様，図13 の模型に示したよらな機構による化学結合によって達 成されるものと考光てよからう。

ガラスと金属の接着機構のらち, 本編に拈いては, 鉄就よびュバール合金に関するものについて述べた。 その他のクロム・銅・アルミニウム・ダングステン・ 白金など，ガラスとの封着に用いられる多くの金属に ついては後編にて取り扱らこととする。

な抗，本稿作成にあたって有益な資料を提供された 鮫島幸治氏に謝意定表する。

\section{参考文 献}

1) Partridge, J. H., "Glass to Metal Seals" (1949) Soc. Glass Tech., Shefield England.

2) Shand, E. B., "Glass Engineers Handbook" (1958) Mc Graw-Hill Book Co.

3) Espe, W., u. M. Knoll, "Werkstoffkunde der Hochvacuumtechnik, McGraw-Hill Book Co.

4) American Ceramic Society, "Technical Papers of the IV International Congress on Glass" (1962) Plenum Press, New York. 
5) Mackenzie, J.D., "Modern Aspects of the Vitreous State” (1963) Butterworth.

6) Koh1, W.H., "Handbook of Materıals and Techniques for Vacuum Devices" (1967) Reinhold Pub Corp

7）宮城精吉, “ガラスと金属の熔封”（1943）オーム社

8）舟曳春吉訳, “真空管材料学” (1942) 有象堂

9）深川修吉, “真空管材料” (1956) オーム社

10）真空用金属材料研究委員会, “電子管用金属材料” (1958) 丸善

11）成瀬 省, “ガラス工学” (1958) 共立出版

12）沢井郁太郎，森谷太郎，田代 仁，“ガラス・ホウロウ” （1959）日刊工業

13）森谷太郎, 成頼 省, 功刀雅長, 田代 仁編, ”ガラス 工学ハンドブック” (1963) 朝倉書店

14）窯業協会編, “窟業工学ハンドブック”（1966）技報堂

15）池田 豊, 致業協会誌, 72, 29 (1964).

16）池田 豊, 真空用金属材料研究報告, No. 13, p. 221 （1966）日本金属学会真空用金属材料研究委員会

17）池田 豊, 照明学会誌, 49, 642 (1965).

18）池田 豊, 村井治郎, 新日本電気技報, 1, 100 (1966).

19）池田 豊, エレクトロニクス, 2, 1543 (1957).

20）池田 豊, 真空, 2, 184 (1959).

21）池田 豊, エレクトロニクスダイジェスト， No. 14, p. 38 (1959).

22）池田 豊, 電子材料, 3, 11-8 (1964).

23）池田 豊, 新金属, 2, 8-29, 9-39, 10-27 (1964).

24) King, B. W., J. Amer. Ceram. Soc., 15, 483 (1932); 16, 232 (1933); 17, 215 (1934).

25) Hull, A. W., E. E. Burger, and L. Navias, J. App. Phys., 12698 (1941)

26) Howe, E. E., and R. L. Fellows, J. Amer. Ceram. Soc., 20, 319 (1939).

27) King, B. W., H. P. Tripp, and W. H. Duckworth, ıbıd., 42, 504 (1959).

28) Zackay., V.F , D. W. Mitchell, S P. Mitoff, and J.A

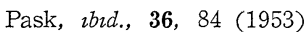

29) Mitoff, S.P., $\imath b \imath d ., 40,118$ (1957).

30) Fulrath, R. M., S. P. Mitoff, and J. A. Park, $\imath b \imath d$., 40, 269 (1957).

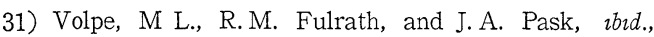
42, 102 (1959).

32) Cline, R. W., R M. Fulrath, and J. A. Pask, ıbıd, 44, 423 (1961).

33) Hagan, L. G., and S.F. Ravitz, ıbıd., 44, 428 (1961).

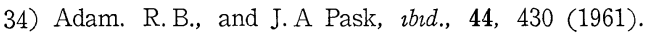

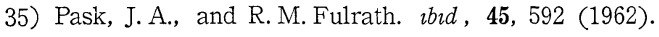

36) Healey, J H, and A. I. Andrews, $2 b \imath d ., 34,207$ (1951).

37) Harrison, W. H, J C. Richmond, J. W. Pitts, and S G. Benner, ibıd., 35, 113 (1952).

38) Borom, M.P., and J.A. Pask, ibıd., 49, 1 (1966).

39) O'brien, W. J., and G. Ryge, ıbıd., 47, 5 (1964).

40) Spriggs, R. M., and A. L. Pricedberg, ıbıd., 43, 252 (1960).

41) Kautz, K, ibid., 20, 115 (1937).

42）田代 仁, 窯業協会誌，57，70，86， 124，149 (1949), 58, 51, 204 (1950).

43）鮫島幸治, 西山雅男, ibid., 74, 301 (1966).

44）鮫島幸治，西山雅男，新日本電気技報，2，39（1967）。

45) Adam. H., J. Soc. Glass Tech., 38, 285 (1934).

46）岡村史良, 見目正道, NEC日本電気技報, 1, 2-2 (1948).

47）池田 豊, 窯業協会誌, 58, 201 (1950).

48）池田 豊, 電子工業, 9, 825 (1964).

49）鮫島幸治, 西山雅男, 窯業協会誌, 73, 156 (1965).

50) Hull, A. W., and E. E. Burger, Physics, 5, 384 (1934).

51) Pfeil, L. B., J. Iron Steel Inst., 121, 501 (1929); 123, 237 (1931).

52）池田 豊，鮫島幸治，大井川嘉造，材料試験， 11，515 (1962).

53) Ikeda, Y., and Y.Sameshima, Proc. 6th Japan Congr. Test. Mat., p. 124 (1963).

54) Kingery, W. O., Bull. Amer. Ceram. Soc., 35, 108 (1956).

55) Pask, J.A., Proc. I. R.E., 36, 286 (1948).

56) Weiss, W., Glastech. Ber., 29, 386 (1956).

57) Oel, H. J., Ber. Deut. Ker. Gesell., 38, 258 (1961).

58) Corning Glass Works, "Properties of Selected Commercial Glasses” (1960).

59) Hickman, J. W., and E. A. Guldbrausen, Trans. Amer. Inst. Mining, 171, 344 (1947).

60) Pask, J. A, Proc. Inst. Radio Eng., 36, 286 (1948).

61) Abendroth, R. P., "Materials Research and Standards", p. 459 (1965).

62）小野員正，応用物理， 25, 500 (1956).

63) 徳光 直, 岡本宏章, 日本物理学会誌, 2, 4 (1947).

64) Notis, M. R., J. Amer. Ceram. Soc., 45, 412 (1962).

65）鷹木 清, 電気通信研究所成果報告, No.1333 (1959).

66）池田 豊, 鮫島幸治, 材料試験, 10, 792 (1961).

67) Sameshima, Y., Proc. 7th Japan Congr. Test. Mat., p. 99 (1964).

68) Ikeda, Y., and Y. Sameshima, ıbıd., p. 127 (1964). 